\title{
Інфодемія як метод маніпуляції на телеканалах 1+1, СТБ, ICTV, IHTEP
}

\section{Пуцята I.C.}

\section{Інститут права, психології та інновачійної освіти НУ «Львівська політехніка»}

Розвідка присвячена вивченню національних аспектів формування інфодемії у зв'язку з суспільно-політичною ситуацією в країні, що виникла на тлі пандемії COVID-19. Це явище розглянуто як основа маніпулятивного впливу на суспільну свідомість. Сучасні телеканали є структурами, які оперативно отримують інформацію, аналізують ії на предмет актуальності, можуть «дозувати» її обсяги та коригувати зміст. Контроль за інформацією та спосіб її інтерпретації дозволяє маніпулювати масовою свідомістю, створювати модель суспільної поведінки, що запрограмована та бажана для окремих груп, які прагнуть досягти різних цілей, як правило, політико-економічного характеру.

Маніпулятивні технології (посилання на анонімний авторитет, емоційний резонанс, буденна розповідь, ефект присутності, стереотипізація тощо), а також соціально-психологічна природа поширення інформації, дозволяють говорити про високий потенціал телебачення як інструменту управління суспільством і небезпеки недостовірної інформації, а також їі «ангажованого трактування».

У такий спосіб, саме політичний компонент інфодемії визначає суть її національної версії та свідчить про соціальну безвідповідальність олігархічних сил та телеканалів, які їх обслуговують, транслюючи дезінформацію про поширення вірусу та боротьбу українського уряду за здоров'я громадськості.

Для ефективної боротьби з поширенням цього явища держава повинна вжити відповідних заходів, сприяти створенню справді незалежного ЗМК, здатного об'єктивно оцінювати та подавати новину, формувати в Україні інформаційний простір, в основі якого лежить вимога правдивості, об'єктивності, плюралізму щодо достовірності фактів та аргументів, переданих суспільній свідомості.

У результаті дослідження зроблено висновок, що унікальність українського варіанту інфодемії полягає в тому, що цей інструмент всеукраїнські телевізійні канали використовують не для підвищення власних рейтингів та прибутків, а для маніпуляції свідомістю громадян та отримання електоральної підтримки в політичній боротьбі, яку ведуть у країні олігархічні клани.

Ключові слова: інфодемія; COVID-19; маніпулячія; політика; телеканали; влада.

\section{1. Вступ}

Постановка проблеми. У зв'язку з розвитком глобального інформаційного простору й виходу телебачення на провідні ролі в системі надання інформації, можна навести висловлювання французького соціолога П. Бурдьє, зроблене ним ще наприкінці XX ст., про «формування телебаченням «екстраординарних новин», які забезпечать телеканалам високий рей- тинг, а також дозволять виконувати функцію формування «громадської думки» за допомогою впровадження в масову свідомість різного роду ідей, концепцій, переконань, включно із чужорідних для соціуму» (Bourdieu, 1996).

Нині високий рівень технологічного, інформаційного та аналітичного забезпечення діяльності провідних телеканалів, їх авторитет серед більшості населення як головних «постачальників новин» (при не-
Putsyata I., Lecturer of the department of journalism and mass media, Institute of Jurisprudence, Psychology and Innovative Education, National University "Lviv Polytechnic", e-mail: Iryna.S.Putsiata@lpnu.ua, ORCID: https://orcid.org/0000-0001-9047-6245, National University "Lviv Polytechnic", Institute of Jurisprudence, Psychology and Innovative Education, 1/3 Kniazia Romana St., Lviv, 79000, Ukraine
Пуцята І.С., старша викладачка кафедри ЖзМк Інституту права, психології та інноваційної освіти НУ "Львівська політехніка», e-mail: Iryna.S.Putsiata@lpnu.ua, ORCID: https://orcid.org/0000-0001-9047-6245, НУ "Львівська політехніка", Інституту права, психології та інноваційної освіти, вул. Князя Романа 1/3, Львів, 79000, Україна 
достатньому рівні їх соціальної відповідальності та високій політичній заангажованості), створюють умови для активної маніпуляції громадською думкою шляхом поширення новин, разом із сумнівно достовірними, так званими «фейками».

Маніпулятивний складник інформаційних повідомлень стає в наш час суттєвою небезпекою для соціального благополуччя суспільства, для національної безпеки України, якій доводиться стримувати «інформаційний натиск» в трьох глобальних вимірах: у військово-політичному, соціально-економічному та соціально-медичному.

При цьому останній (соціально-медичний) аспект маніпулятивного впливу пов'язаний з тим, що в 2020 р. небезпека коронавірусної інфекції (COVID-19) набула глобальних масштабів, а в українському телевізійному інформаційному просторі пандемія, сукупно зі страхами одних людей і політичними цілями інших, породила новий соціальний феномен інфодемію.

Актуальність дослідження полягає в його науковопрактичній значущості. Важливим стає вивчення явища «інфодемії» як феномена, породженого пандемією COVID-19 та внутрішньою політичною ситуацією в Україні, з погляду маніпулятивних практик, які використовують провідні телевізійні канали України: 1+1, СТБ, ІСТV, Інтер.

Огляд літератури й аналіз останніх досліджень та публікацій. Проблеми маніпулятивного впливу 3МІ в останні роки досліджували такі вчені, як: Б.М. Калініченко (2021), І.В. Головко (2021), І. Костиря (2013), В.Ю. Степанов (2010) та ін. Проте в працях дослідників не розкрита найактуальніша проблема, якою $€$ інфодемія -сучасний та найбільш ефективний інструмент маніпулятивного впливу на громадську свідомість. Найкраще проблему інфодемії розглядають зарубіжні вчені, на праці яких ми спираємося в цьому дослідженні (Castells, 2007; García-Saisó et al., 2021; Mesquita et al., 2020; Zielinski, 2021).

Зв'язок авторського доробку з важливими науковими та практичними завданнями полягає в тому, що в цій статті на матеріалах інформаційного характеру, що транслюються телеканалами: 1+1, СТБ, ICTV, Інтер, показана деструктивна природа інфодемії. Автором виділені невирішені раніше частини цієї проблеми, зокрема досліджені особливості феномена інфодемії, яка сформувалася на національному ґрунті.

Новизна статті полягає в тому, що розкрито національні аспекти формування інфодемії у зв'язку з суспільно-політичною ситуацією в країні.

Метою статті є дослідження інфодемії як методу маніпуляції на прикладі інформаційної діяльності телеканалів: 1+1, СТБ, ICTV, Інтер.

Завданнями дослідження $€$ визначення поняття «інфодемія», аналіз її національної специфіки та шляхів протидії цьому негативному явищу в українському медіапросторі.
Методи дослідження. Зважаючи на мету та завдання дослідження, у статті використано методи діалектичного аналізу й синтезу, компаративістський метод, а так само метод змістовного розбору та класифікації інформаційних повідомлень. Ці методи використовувалися комплексно, відповідно до логіки дослідження, яка обумовила алгоритм дій, що дало змогу досягти поставленої мети: на першому етапі дослідження автор здійснив узагальнення теоретичних підходів до визначеної проблеми; подальший алгоритм дій передбачив безпосередньо роботу з інформаційними повідомленнями, їх класифікацію відповідно до джерела надходження; на третьому етапі автор звернувся до методики компаративістського аналізу, який дозволив провести аналіз текстів інформаційних повідомлень, дав змогу встановити наявність у цих повідомленнях недостовірної інформації та вийти на узагальнення тих факторів, що обумовлюють наявність в українському телевізійному дискурсі маніпулятивного складника, характерного для інфодемії.

Фактологічним матеріалом для статті стали інформаційні повідомлення, які транслювалися в останні роки провідними українськими телеканалами та мали ознаки недостовірності, формуючи підстави для створення в суспільстві панічних настроїв, відчуття невдоволення діями влади, що характерні для інфодемії.

\section{2. Результати й обговорення}

Незважаючи на те, що з початку пандемії COVID19 пройшло не так багато часу, очевидний масштаб загрози, яку вона представляє. При цьому наслідки COVID-19 аж ніяк не обмежуються проблемою летальності -пандемія зачепила практично всі сфери життя суспільства. Цей вірус зробив те, чого за останні 100 років не вдавалася жодному іншому вірусу або бактерії: замкнув значну частину населення у власних оселях, паралізував не лише соціальне, а й економічне життя багатьох держав.

У зв'язку з цим у 2020-2021 рр. XXI ст. коронавірус став найбільш обговорюваним явищем у зМІ. Ще більшими темпами, ніж новий вірус з моменту його появи, почала поширюватися інформаційна епідемія або так звана інфодемія. Спробуємо дати визначення новому терміну, уведеного під час пандемії і зумовленого комунікаційними процесами в інформаційному суспільстві.

Зазначимо, що це поняття вперше було використане під час спалаху атипової пневмонії SARS у 2003 р., проте найбільшу актуальність набуло лише через 17 років, коли суспільство вийшло на новий рівень інформатизації в умовах виникнення нових загроз у сфері громадського здоров'я. Цей термін набув поширення після того, як 5 лютого 2020 р. під час Мюнхенської конференції безпеки директор Всесвітньої організації охорони здоров'я (ВООЗ) Т. Гебрейєсус заявив, що боротьба з пандемією COVID-19 супрово- 
джується боротьбою з «інфодемією», яка стає найважливішим напрямком діяльності ВООЗ та інших організацій, залучених до боротьби з пандемією ("Managing the COVID-19 infodemic: Promoting healthy behaviours and mitigating the harm from misinformation and disinformation," 2020).

Така ситуація не $є$ новою, враховуючи те, що в будь-який кризовий період, під час надзвичайних ситуацій, що впливають на стан здоров'я людей, у суспільстві починає стрімко розповсюджуватися інформація, яка не завжди відповідає дійсності. Зазначимо, що українські дослідники (Demyanenko, 2020; Kitsa, 2016; Pryhornytska, 2017) в останні роки досить активно вивчають механізми розповсюдження недостовірної інформації.

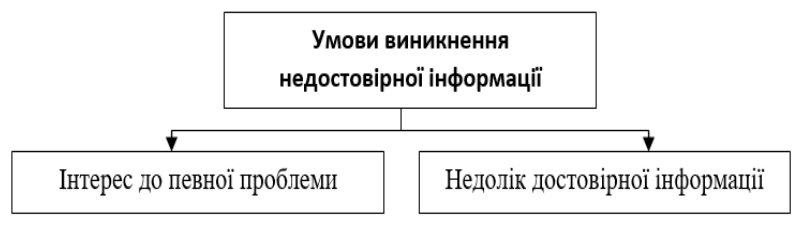

Рис. 1. Умови виникнення недостовірної інформації та її поширення (складено автором)

Аналіз праць вітчизняних науковців доводить, що в основі цього механізму лежать дві обов'язкові умови (рис. 1), синтез яких сприяє розповсюдженню «фейків», що треба мати на увазі й у процесі дослідження інфодемії, яка апелює до безсумнівної суспі- льної значущості інформації, пов'язаної з пандемією та недостатнім обсягом об'єктивної інформації, яка всебічно та об'єктивно інформує суспільство про реальну епідеміологічну ситуацію, про наслідки захворювання, про ефекти вакцинації тощо.

Ця ситуація пов'язана з тим, що інформацію, яку потребує суспільство, відповідні органи та засоби інформування ще не накопичили, більш того світова наукова спільнота все ще не змогла сформувати єдиної позиції з питань, які хвилюють громадян. Отже, актуальність інформації про пандемію та її недостатність $є$ тими умовами, на яких формується «інфодемічний дискурс».

Сучасна ситуація ускладнена тим, що неправдиві новини активно поширюють сучасні 3MI, а також тим, що в епоху цифрових трансформацій посилюється швидкість інформаційного обігу, що формує «ідеальні» умови для розвитку інфодемії.

Як зазначає ВООЗ, інфодемія являє собою надлишок інформації, яка розповсюджується як онлайн, так і офлайн, містить навмисні спроби дезінформації 3 метою дискредитації заходів, спрямованих на збереження громадського здоров'я; ії метою є просування альтернативних планів вирішення проблем ("Managing the COVID-19 infodemic: Promoting healthy behaviours and mitigating the harm from misinformation and disinformation," 2020).

Аналіз наукової літератури, що присвячена цій проблемі, засвідчує, що в сучасному науковому дис-

\begin{tabular}{|c|c|c|c|}
\hline & 02.2018 & 02.2019 & 08.2020 \\
\hline $1+1$ & $35.4 \%$ & $24.2 \%$ & $24.2 \%$ \\
\hline Україна & $21.7 \%$ & $20.3 \%$ & $18.9 \%$ \\
\hline ICTV & $19.9 \%$ & $15.2 \%$ & $16.8 \%$ \\
\hline СТБ & $14.6 \%$ & $12.8 \%$ & $14.6 \%$ \\
\hline Iнтер & $22.3 \%$ & $14.7 \%$ & $13.0 \%$ \\
\hline 112 Україна & $7.7 \%$ & $8.2 \%$ & $12.0 \%$ \\
\hline NewsOne & $4.3 \%$ & $3.1 \%$ & $9.4 \%$ \\
\hline Прямий канал & | 1.1\% & $2.1 \%$ & $6.3 \%$ \\
\hline ZIK & $3.4 \%$ & $2.4 \%$ & $6.3 \%$ \\
\hline Новий канал & $6.2 \%$ & $6.4 \%$ & $4.9 \%$ \\
\hline 5 канал & $3.0 \%$ & $2.3 \%$ & $4.7 \%$ \\
\hline 24 канал & $2.2 \%$ & $1.4 \%$ & $4.6 \%$ \\
\hline Ecnpeco TB & | $1.0 \%$ & $1.3 \%$ & $4.2 \%$ \\
\hline UA: Перший & $1.9 \%$ & | $1.2 \%$ & $2.3 \%$ \\
\hline Громадське ТБ & | $0.8 \%$ & $0.3 \%$ & $2.0 \%$ \\
\hline ATR & $0.0 \%$ & $0.0 \%$ & $0.7 \%$ \\
\hline Інші & $0.0 \%$ & $0.6 \%$ & $\mid 0.8 \%$ \\
\hline
\end{tabular}

Рис. 2. Рейтинг «довіри» провідним телеканалам України з боку глядачів (Razumkov Center, 2020) 
курсі інфодемія розглядається як поширення новин про кризові події у сфері громадського здоров'я, у соціально-економічній сфері, коли ця інформація неконтрольовано транслюється 3МІ й посилює в суспільстві почуття ризику, невизначеності, страху, неспокою, тим самим дезорганізуючи соціальні відносини та політику держави в сфері охорони здоров'я.

У цьому контексті ще раз звернемо увагу на те, що нині «вільна комунікація», про яку писав М. Кастельс (Castells, 2007), стала основою неконтрольованого глобального інформаційного обміну, що створює умови для миттєвого новинного обміну, варіативності та інтерпретації інформації. Швидкість поширення інфодеміі створює передумови для того, щоб читач, телеглядач і радіослухач постійно одержував величезний потік будь-якої інформації про коронавірус.

У центрі феномена інфодеміі, як ії̈ найважливішого суб'єкта, виступає телебачення, яке володіє величезними можливостями для поширення повідомлення різного об'єму, змісту й ступеня достовірності.

За даними Українського центру економічних та політичних досліджень ім. О. Разумкова українці мають різний рівень довіри до інформації, яку розповсюджують телеканали (рис. 2).

Як бачимо, телеканали: 1+1, СТБ, ICTV, Інтер $є$ лідерами в рейтингу довіри, але це аж ніяк не сприяє об'єктивності їх контенту. Більше того, ці канали стали найбільшими розповсюджувачами інформації, що має деструктивний характер, викривлює ситуацію із коронавірусом, спотворює імідж держави як головного борця з епідемією в Україні.

Найбільш резонансним та кричущим проявом інфодемії в нашій країні $€$ фейкова інформація російських 3MІ, яка була розповсюджена телеканалом 1+1: йшлося про нібито роботу «таємних американських біолабораторій» в Україні. Це повідомлення стало приводом для того, щоб кремлівські медіа «виявили» одразу 15 таких лабораторій на території України, які «курирують спецагенти ЦРУ», і в яких «міг бути створений нинішній коронавіpус» (Novynarnia, 2020).

Відсутність об'єктивності, схильність до «викривлення» інформації спостерігаються й в політиці телеканалу «Інтер». Так, наприклад, у програмі «Подробиці» (06.01.21 20:12) з'явилася новина, що першу партію китайської вакцини, а це 700 тисяч доз, Україна отримає в лютому. Однак, виявляється, таємна імунізація вже почалася. ЗМІ поширює інформацію, що багаті та впливові - роблять собі щеплення контрабандною європейською сироваткою. Повідомлення стосовно «ризиків щеплення»: на явно «фейковому» рівні "досліджувався» склад вакцини, найбільша увага зосереджена на тому, що для багатьох людей вакцинація може стати скоріше небезпечною, аніж корисною (Burkovskyi, 2021).

Також «Інтер» протягом останнього року транслював й інші новини сумнівного, з огляду на об'єктивність, характеру: у сюжетах цього телеканалу звучали думки політиків, які інформували про те, що у Верховній Раді планують важкі наслідки в разі відмови від російської вакцини (08.02.2021); констатували, що життя українців для влади менш важливі, ніж реноме борців з Росією (23.03.21); Уряд дискредитує вакцину «Супутник-V» в інтересах транснаціональних компаній США; в Україні почнуть збір підписів за використання вакцини «Супутник V» (18.03.21); що в України був шанс виробляти російську вакцину, але влада вибрала смерть для населення» (18.03.21) тощо. Як бачимо, перелік цих тематичних блоків свідчить про явну ангажованість, однобічність поданої інформації.

Панічні настрої в суспільстві формував і телеканал «ICTV», який в анонсах програми «Факти» використовував явно «інфодемічний дискурс», звертався до фактів, що були не тільки не підтвердженими, але й явно "фейковими», зазначивши, що кількість померлих від коронавірусної інфекції штучно занижується, а «померлі від коронавірусу лежать просто посеред лікарень» («Факти». ICTV. 21.06.21).

Таку ж панічну інформацію надавав телеглядачам і телеканал «СТБ», анонсуючи новини: «Коронавірус шириться планетою та вбиває землян: 15 тисяч інфікованих людей за добу» (15.02.2021); «Гонконгські медики оприлюднили шокуючу заяву про шляхи поширення коронавірусу» (15.05.2021); «Епідемія коронавірусу здатна спровокувати масштабну світову економічну кризу» (14.07.2021).

Аналіз інформаційних матеріалів, які розповсюджують провідні українські телевізійні канали, засвідчує, що переважна їх більшість це:

- алармістські прогнози;

- критика влади в питаннях вакцинації та відмови від російської вакцини;

- конспірологічні теорії походження вірусу;

- панічні «свідчення» про те, що відбувається;

- псевдонаукові міркування про небезпеку вакцинації;

- про шкоду й відсутність необхідності носіння масок.

У цьому аспекті звернемо увагу на те, що інформаційний контекст має явно виражений однобічний, заангажований характер і, на наше переконання, сучасний «телевізійний тренд» на «інфодемічне» трактування подій та фактів $\epsilon$ наслідком «олігархизації» сучасного телевізійного простору України, враховуючи приналежність досліджуваних каналів до структур, що мають «претензії» до чинної української влади, або ж намагаються впливати на суспільно-політичну ситуацію в країні (В. Пінчук (ICTV, СТБ), І. Коломойський (1+1), Д. Фірташ, С. Льовочкін (Інтер)). Це підтверджують думки експертів, які зазначають, що інвестиції в телеконтент всеукраїнських 3MІ здійснювались задля формування суспільної думки, а відтак -для впливу на вище керівництво держави (Holovnov, 2021).

Унікальність «українського штаму інфодемії» полягає в тому, що цей інструмент використовують не сті- 
льки для отримання високих рейтингів та відповідно підвищення прибутків телеканалів, скільки для маніпуляції свідомістю громадян та отримання електоральної підтримки в політичній боротьбі. Фактично сучасний український «інфодемічний» дискурс формується на тлі медіатизації політики та політизації $3 \mathrm{MI}$, коли в міру розвитку в країні демократичних відносин діяльність корпоративних структур на інформаційному ринку все більше підкорена логіці попиту та пропозиції, пробуджуючи нові форми комунікації, що стають все більш агресивними та неконтрольованими (Kostyria, 2013).

Як зазначають учені, COVID-19 дивним чином замінив собою політичну ідеологію, і сам став ідеологією. Суб'єкти великої політики створили умови для того, щоб вірус був інструменталізований, розглядався не просто як хвороба, а як вселенський ворог, впоратися з яким влада не в змозі. Неймовірна популярність і миттєва інфодемізація пандемії пояснюється тим, що вона зайняла місце справжньої національної ідеології на телевізійних екранах. При цьому обсяги трансльованої інформації не дозволяють її ретельно перевірити, що сприяє створенню фейків, спрямованих на маніпуляцію соціально-політичною свідомістю населення (Fanailova, 2021).

Наголосимо, що саме політичний складник інфодемії визначає її сутність та свідчить про соціальну безвідповідальність олігархічних сил та телеканалів, що їх обслуговують, транслюючи явну дезінформацію.

Як зазначають експерти, така дезінформація знижує готовність людей дотримуватися настанов у сфері громадського здоров'я (носіння масок, дотримання фізичної дистанції тощо) і зменшує ймовірність того, що державні зусилля в подоланні пандемії досягнуть успіхів, при тому, що неконтрольована інфодемія здатна значною мірою підвищити рівень захворювання на COVID-19 ("'Infodemiia' dezinformatsii pro COVID-19 shkodyt zdoroviu ukraintsiv - ziasovano v doslidzhenni na zamovlennia OON ['Infodemia' of misinformation about COVID-19 is harmful to the health of Ukrainians found in a study commissioned by the UN]," 2021).

В українському варіанті, епідемія чуток і теорій несе за собою численні небезпеки й загрози для суспільства. По-перше, падає рівень довіри до офіційних джерел інформації, організацій з охорони здоров'я, вчених і держави в цілому. Це призводить до відмови від дотримання запобіжних заходів, до лікування народними методами, відмови від вакцинації і навіть заперечення COVID-19 як захворювання в цілому, що забирає людські життя й допомагає безконтрольному поширенню вірусу.

По-друге, недостовірна інформація перешкоджає консолідації суспільства й прояву солідарності в ньому в кризових умовах, загострює соціальні конфлікти в українському суспільстві, поляризує думки з питань COVID-19, провокує ненависть і підвищення суспільної напруженості.

Відповідно в цих умовах стає важко координувати дії держав, світових організацій, науково-дослідних груп, окремих людей тощо, але ж саме згуртованість і солідаризація суспільства має значну роль у довгостроковій боротьбі з поширенням і наслідками коронавірусної інфекції, зокрема й соціальноекономічними. Прояви цієї небезпеки спостерігаємо протягом усього періоду пандемії i, ймовірно, побачимо їх і в майбутньому.

Безумовно, що явище інфодемії потребує відповідної реакції, передусім із боку української влади, яка вже почала рухатися в правильному напрямку, розробивши Проєкт Закону «Про запобігання загрозам національній безпеці», пов'язаним із надмірним впливом осіб, які мають значну економічну або політичну вагу в суспільному житті (олігархів). Реалізація проєкту позбавить олігархів можливості впливати на суспільство через підконтрольні 3МІ (Proekt Zakonu pro zapobihannya zahrozam natsional'niy bezpetsi, pov'yazanym iz nadmirnym vplyvom osib, yaki mayut' znachnu ekonomichnu abo politychnu vahu $v$ suspil'nomu zhytti (oliharkhiv) [Draft Law on Prevention of Threats to National Security Related to Excessive Influence of Persons Who Have Significant Economic or Political Weight in Public Life (Oligarchs)], 2021).

Цей крок $\epsilon$, безумовно, прогресивним, але існують й інші варіанти розв'язання проблеми інфодемії в Україні. Наприклад, на часі $€$ створення національної і/або міжнародної єдиної бази «фейків», інформування українського суспільства про її існування й необхідності перевіряти всі сумнівні факти, звертаючись до цієї бази.

Такий підхід, на нашу думку, є найважливішим елементом боротьби з інфодемією, який надає кожному громадянину необхідний обсяг об'єктивної інформації, підтвердженою думкою авторитетних учених, медиків, політиків, осіб, які перемогли хворобу.

\section{3. Висновок}

Проведене дослідження дозволяє стверджувати, що інфодемія в Україні - не менш небезпечне й заразне явище, ніж COVID-19. Вона має явно політично заангажований, маніпулятивний характер і створює загрози стабільності держави. Інфодемія посилює соціальну напругу й тривогу, провокує появу ризиків у всіх сферах соціального життя українців: перешкоджає консолідації та солідаризації суспільства, провокує хвилю ненависті та насильства.

При цьому сучасна конфігурація національного інформаційно-комунікаційного середовища сприяє неймовірній швидкості поширення неперевіреної або помилкової інформації, що значно ускладнює боротьбу з кризовою подією і соціальними феноменами, пов'язаними з нею.

Для ефективної боротьби з поширенням цього явища держава повинна вживати відповідні заходи, сприяти створенню дійсно незалежного телебачення, яке здатне об'єктивно оцінювати й подавати новини, формувати в Україні інформаційний простір, у центрі якого лежить вимога правдивості, об'єктивності, плю- 
ралізму думок, заснованого на достовірності фактів і аргументів, що транслюються в суспільну свідомість.

Відповідно перспективним напрямком подальшого дослідження $є$ визначення тих факторів та механізмів державного реагування, що дозволять ефективно протидіяти інфодемії в українському інформаційному просторі.

\section{References}

Bourdieu, P. (1996). Sur la television: Suivi de L'emprise du journalisme. Liber/Raisons d'agir.

"Infodemiia" dezinformatsii pro COVID-19 shkodyt zdoroviu ukraintsiv -ziasovano $v$ doslidzhenni na zamovlennia OON ["Infodemia" of misinformation about COVID-19 is harmful to the health of Ukrainians - found in a study commissioned by the UN]. (2021, March 3). UNICEF. https://www.unicef.org/ukraine/press-releases/ infodemic-covid-19-disinformation-bad-ukrainians-health -study-un-finds.

Burkovskyi, P. (2021). Chy nadovho «Inter» ziskochyv z holky "russkoho myra»? [How long did "Inter" jump out of the needle of the "Russian world"?]. https://dif.org.ua/ article/chi-nadovgo-inter-ziskochiv-z-golki-russkogo-mira (in Ukrainian).

Castells, M. (2007). Communication, Power and Counterpower in the Network Society. International Journal of Communication, 1, 238-266.

Demyanenko, L. (2020). Osoblyvosti protydii nedostovirnii (feikovii) informatsii $v$ sotsialnykh merezhakh [Peculiarities of counteraction to unreliable (fake) information in social networks]. Naukovi pratsi Natsionalnoi biblioteky Ukrainy imeni V. I. Vernadskoho [Scientific works of the National Library of Ukraine named after V.I. Vernadsky], 58, 277-289 (in Ukrainian).

Fanailova E. (2021). Vlast' y vyrus [Power and the virus]. Radio Svoboda. https://www.svoboda. org/ a/31161240.html (in Russian).

García-Saisó, S., Marti, M., Brooks, I., Curioso, W., González, D., Malek, V., Medina, F. M., Radix, C., Otzoy, D., Zacarías, S., Dos Santos, E. P., \& D'Agostino, M. (2021). The COVID-19 Infodemic. Revista Panamericana de Salud Pública, 45, 1. https://doi.org/10.26633/rpsp.2021.56.

Holovko, I. V. (2016). Politychne manipuliuvannia vs svoboda slova: osoblyvosti proiavu u demokratychnykh suspilstva [Political manipulation vs freedom of speech: features of manifestation in democratic societies]. Suchasne suspilstvo [Modern society], 1, 18-30 (in Ukrainian).

Holovnov, S. (2021). Yak oliharkhy realizuiut monopoliiu na informatsiiu [How the oligarchs exercise a monopoly on information]. ttps://biz.censor.net/resonance/3261024/ yak_olgarhi_realzuyut_monopolyu_na_nformatsyu (in Ukrainian).

Kalinichenko, V. M. (2021). Rol zasobiv masovoi informatsii v informatsiinii viini: politychni determinanty vplyvu ta protydii: dys. ... dokt. polit. nauk [The role of the media in the information war: the political determinants of influence and counteraction] [Unpublished doctoral dissertation] (in Ukrainian).

Kitsa, M. O. (2016). Feikova informatsiia v ukrainskykh sotsialnykh media: poniattia, vydy, vplyv na audytoriiu [Feykova information in Ukrainian social media: concepts, types, impact on the audience] Naukovi zapysky [Ukrainskoi akademii drukarstva] [Scientific notes
[Ukrainian Academy of Printing], 1, 281-287 (in Ukrainian).

Kostyria, I. (2013). Mediatyzatsiia polityky ta polityzatsiia ZMI yak tendentsii politychnoho protsesu $v$ Ukraini [Mediatization of politics and politicization of the media as trends in the political process in Ukraine]. Politychnyi menedzhment [Political Management], 1-2, 109-118 (in Ukrainian).

Managing the COVID-19 infodemic: Promoting healthy behaviours and mitigating the harm from misinformation and disinformation. (2020, September 23). WHO | World Health Organization. https://www.who.int/news/item/23 -09-2020-managing-the-covid-19-infodemic-promotinghealthy-behaviours-and-mitigating-the-harm-frommisinformation-and-disinformation.

Mesquita, C., Oliveira, A., Seixas, F. \& Paes, A. (2020). Infodemia, fake news and medicine: science and the quest for truth. International Journal of Cardiovascular Sciences, 33(3), 203-205. https://doi.org/10.36660/ ijcs. 20200073.

Novynarnia (2020). Vid «sekretnykh laboratorii» do «rozpadu Ukrainy»: yak prokremlivski ZMI shyriat feiky pro koronavirus [From "secret laboratories" to the "disintegration of Ukraine": how pro-Kremlin media spread fakes about the coronavirus]. https://novynarnia. com/2020/05/22/ euvsdisinfo/ (in Ukrainian).

Proekt Zakonu pro zapobihannya zahrozam natsional'niy bezpetsi, pov'yazanym iz nadmirnym vplyvom osib, yaki mayut' znachnu ekonomichnu abo politychnu vahu $v$ suspil'nomu zhytti (oliharkhiv) [Draft Law on Prevention of Threats to National Security Related to Excessive Influence of Persons Who Have Significant Economic or Political Weight in Public Life (Oligarchs)] (1780-IX). (2021). The Verkhovna Rada of Ukraine. https:// w1.c1.rada.gov.ua/pls/zweb2/webproc4_1? pf3511=72105 (in Ukrainian).

Pryhornytska, O. (2017). Feikova informatsiia v sotsialnykh media: vyiavlennia, otsinka, protydiia [Fake information in social media: detection, evaluation, counteraction]. Naukovi pratsi Natsionalnoi biblioteky Ukrainy imeni V. I. Vernadskoho [Scientific works of the National Library of Ukraine named after V.I. Vernadsky], 48, 311-321 (in Ukrainian).

Razumkov Center. (2020, September 30). lak zminylys upodobannia ta interesy ukraintsiv do zasobiv masovoi informatsii pislia vyboriv 2019 r. ta pochatku pandemii COVID19 [How Ukrainians' preferences and interests in the media have changed since the 2019 elections and the start of the COVID-19 pandemic]. https://razumkov.org.ua/ napriamky/sotsiologichni-doslidzhennia/yak-zminylysupodobannia-ta-interesy-ukraintsiv-do-zasobiv-masovoiinformatsii-pislia-vyboriv-2019r-ta-pochatku-pandemiicovid19-serpen-2020r (in Ukrainian).

Stepanov, V.Yu. (2010). Informatsiina polityka: manipuliatyvni tekhnolohii u suspilstv [Information policy: manipulative technologies in societies]. URL: http:// www.economy.in.ua/pdf/4_2010/39.pdf (in Ukrainian).

Zielinski, Ch. (2021). Infodemics and infodemiology: a short history, a long future. Rev Panam Salud Publica, 45. https://doi.org/10.26633/RPSP.2021.40. 


\section{Putsyata I. Infodemia as method of manipulation on TV channels $1+1$, STB, ICTV, INTER}

The article reveals the national aspects of the formation of infodemia in connection with the sociopolitical situation in the country, which arose in the background of the COVID-19 pandemic. This phenomenon is considered as the basis of manipulative influence on the public consciousness. Indeed, modern television channels are the structures that quickly receive information and analyse how relevant it is. The author mentions that TV channels can "dose" the volume of information and adjust the content. It is emphasised that it is the control of information and the way it is interpreted that allows manipulating mass consciousness and creating a programmed model of social behavior, which is desirable for certain groups that seek to achieve various goals, usually of political and economic nature. At the same time, modern manipulative technologies (references to anonymous authority, emotional resonance, everyday storytelling, presence effect, stereotyping, etc.), as well as the sociopsychological nature of information dissemination, allow us to talk about the high potential of television as a tool for managing society.

It is important to study the phenomenon of "infodemia" as a phenomenon caused by the COVID-19 pandemic and the domestic political situation in Ukraine in terms of manipulative practices used by leading television channels in Ukraine: $1+1$, STB, ICTV, Inter.

As a result of the study, it was concluded that the uniqueness of the Ukrainian version of infodemia is that this tool is used by these TV channels in order not to increase their ratings and profits, but to manipulate the minds of citizens and gain electoral support.

Thus, it is the political component of the infodemia that determines the essence of its national version and testifies to the social irresponsibility of the oligarchic forces and TV channels that serve them, broadcasting misinformation about the spread of the virus and the struggle of the Ukrainian government for public health.

To effectively combat the spread of this phenomenon, the state should take appropriate measures, promote the creation of the truly independent television that is able to objectively assess and present information, to form the information space in Ukraine, at the heart of which is the requirement of truthfulness, objectivity, pluralism on the authenticity of facts and arguments transmitted to the public consciousness.

Keywords: infodemia; COVID-19; manipulation; politics; TV channels; power.

\section{(c) (i) (2)}

This work is licensed under a Creative Commons Attribution-ShareAlike 4.0 International License. 